\title{
Teachers' Work: Institutional Isomorphism and Cultural Variation in the U.S., Germany, and Japan
}

\author{
by Gerald K. LeTendre, David P. Baker, Motoko Akiba, Brian Goesling, and Alex Wiseman
}

\begin{abstract}
Policy debates in the U.S. are increasingly informed by use of internationally generated, comparative data. Many arguments revolve around whether or not such comparison makes "cultural sense" or whether specific educational activities that appear successful in one nation are "culturally appropriate" in another. These arguments clash with the work of anthropologists and sociologists who demonstrate that global cultural dynamics influence national patterns of schooling around the world. Using both the survey and case study data from the Third International Math-Science Study (TIMSS), we examine the working conditions and beliefs of teachers in Japan, Germany, and the U.S. in order to assess the relative merits of competing theoretical perspectives. We find some differences in how teachers' work is organized, but similarities in teachers' belief patterns. We find that core teaching practices and teacher beliefs show little national variation, but that other aspects of teachers' work (e.g., non-instructional duties) do show variation. We show that models of national cultures of learning or "national teaching scripts" may overemphasize cultural differences and underestimate the impact of institutional isomorphism in schooling. We argue that rather than change values, educational policy will be best served by identifying specific features of teacher work and analyzing how to improve these working conditions.
\end{abstract}

Over the past two decades, educational policy-makers and commentators have engaged in a lively debate about using crossnational studies of teacher's instructional practices to inform U.S. educational practice (Bennett, 1987; Berliner \& Biddle, 1995; Bracey, 1997; Finn, 1992; Ravitch, 1986). Much of this debate focuses on comparisons between American and Asian cultural values about teaching and learning. This debate is organized around the question of whether or not cultural factors will permit superior educational practices used in other countries to be adapted for use in U.S. classrooms: "should be we be more like them or not?"

This seemingly straightforward debate is actually part of a longterm trend toward the internationalization of information used to inform American educational policy debates (see LeTendre \& Baker, 1999; LeTendre, 1999a; Torney-Purta, 1987). This trend has intensified from a Nation at Risk through the internationally calibrated national objectives of Education Goals 2000

Educational Researcher, Vol. 30, No. 6, pp. 3-15 to numerous recent comparisons between achievement of local American school districts and selected foreign nations (Baker, 2001). Whether they think "culture" prevents or makes attractive such comparisons, policy makers and commentators accept the idea advanced by researchers that East Asian cultural values strongly impact instructional practice, classroom management, teacher preparation, and textbook structure (Kinney, 1997-1998; Lewis \& Tsuchida, 1998; Stevenson \& Stigler, 1992; Stigler \& Hiebert, 1998; Stigler \& Stevenson, 1991).

Underlying all this use of cross-national information are two contrasting, yet often unspecified, theoretical assumptions about the precise way culture can be used as a foundation for crossnational comparisons. Each of these views of culture holds different consequences for the way theory can be applied to international educational data, the way such data is used in formation of policy, and how future international studies should guide U.S. educational policy and reform. We begin this article with a description of the salient differences underlying the two dominant cultural perspectives (which we call the "national culture" and "global cultural dynamics" perspectives) and the consequences each perspective has for using cross-national comparisons to reform American education. Since the work of the teacher is central to so many aspects of educational reform, we then undertake several illustrative analyses of the instructional approaches of mathematics teachers and the organization of their work in the U.S., Germany, and Japan. These analyses are used to assess the ability of each perspective to explain cross-national patterns. We end with a discussion of the relative advantages of each approach and with suggestions for how to integrate these strong points into a more comprehensive perspective.

\section{Cultural Images of Teaching and Cross-National Comparisons \\ National Cultures}

The cultural argument most commonly used in debates about improving U.S. teaching practices casts cross-national differences as the product of distinct national cultures that are relatively stable across nations and homogenous within nations. Distinctive cultures are assumed to be more or less synonymous with nations. The underlying logic is that U.S., Japan, and Germany have distinctive cultures that shape central features of schooling such as the types of instructional practices used by national teaching corps. From this perspective the debate often turns on whether or not it is feasible to borrow educational practices from another culture (e.g., Bennett, 1987; Berliner \& Biddle, 1995; Bracey, 
1997; Goya, 1993; Ravitch, 1986; Stevenson \& Stigler, 1992). The dominant image here is that unique national cultural values strongly influence instructional practice, classroom management, teacher preparation, textbook structure, and hence national academic success. (Compare Bracey, 1997 with Bennett, 1987). While often diametrically opposed in terms of their views about what American school reform ultimately should look like, commentators and reformers coming from this perspective assume that national cultures are "hard-wired" to cross-national differences in teaching.

This assumption, and the interest it generates in teaching styles in high performing Asian nations, has been fed by field studies of teaching in East Asian nations, the most prominent and well-developed set of research having taken place in Japan (Cummings, 1980; Hendry, 1986; Kinney, 1997-1998; Lewis, 1995; Lewis \& Tsuchida, 1998; Peak, 1991; Rohlen \& LeTendre, 1996; Stevenson, Azuma, \& Hakuta, 1986). However, in U.S. policy debates, the culturally nuanced presentation is often lost (LeTendre, 1999b).

For example, a popular extension of the distinct national cultures model applied to international studies of schooling is that of national scripts that provide nation-specific ideals for teaching (see Stigler \& Hiebert, 1998). Although it is assumed that at times individual teachers depart from their nation's script, the main image is that of a stable national ideal guiding the bulk of the instructional approaches within a nation (e.g., Stevenson \& Stigler, 1992). This perspective is distinct from that of a national cultural dialog (or cultural dynamic), which can be found in the work of the Spindlers and others (see Spindler, Spindler, Trueba, $\&$ Williams, 1990), and which we discuss under the global cultural dynamic perspective.

The strength of a model of national culture as applied to teaching is that, first, it guides comparisons to focus primarily on any observed cross-national differences. All cross-national differences in teaching become salient and have inherent meaning if it is assumed that strong national cultures are at work behind the scenes in schools and underneath teachers' understandings of their jobs. Second, by assuming that there are national cultures of teaching it is feasible to consider borrowing unique solutions from one nation to the other. When a national culture is assumed to be real and distinct, it can also be assumed that relevant parts of it might be exportable to other nations. The policy argument then becomes centered on whether or not a piece of one culture (related to education) can be borrowed and adapted to fit into another culture, but this ignores how a culture may function as a whole. Lastly, the issue of national cultures provides some explanation of idiosyncratic historical differences between nations in the development of formal schooling.

\section{Global Cultural Dynamics}

In sharp contrast to the theory of national cultures is the theory of cultural dynamics found in comparative anthropological studies (e.g., LeTendre, 2000; Spindler \& Spindler, 1987a; 1987b; Tobin, Wu, \& Davidson, 1989). ${ }^{1}$ In this model local, regional, and national cultures are produced through a continual process of cultural change (see Spindler, Spindler, Trueba, \& Williams, 1990), which, both over time and across place, is often deliberately initiated by members of the culture to further their own political ends (see also Comaroff \& Comaroff, 1992; Wolf, 1992). Schooling in any given society is caught up in this process, as is the teacher's work. This perspective on schooling suggests that schools do not reflect or simply transmit culture but are themselves the product of a cultural dynamic. In Culture Change and Modernization (1977/1984, pp. 4-5) Spindler writes:

Culture . . . refers to shared designs for living. It is not the people or things or behaviors themselves. Culture can be equated with the shared models people carry in their minds for perceiving, relating to, and interpreting the world around them. . . . Sociocultural systems therefore include customary, agreed upon, institutionalized solutions which influence most individuals to behave in a predictable manner most of the time, but never all of the time. (Emphasis added)

For anthropologists and sociologists, institutions play a key role in the cultural dynamic. The rise of global or trans-national institutions now means that all cultures are affected by global forms of institutions (see Dimaggio \& Powell, 1987). Global institutions transect and shape local, regional, or national versions of institutions (i.e., schools). The role of global institutional forces in the isomorphic spread of formal education has been the subject of intense study. The findings from this literature serve to bridge the ideas of a general dynamic cultural theory to macrosociological observations about the spread of global institutions of education (e.g., Fuller \& Rubinson 1992). Further, these arguments offer a clear alternative to the perspective of national cultures of schooling with important implications for the use of cultural arguments in theory testing and debates over the improvement of teaching within any one nation.

In the current world system the global institution of school affects national school cultures. Our definition of institution is derived from works of the "institutionalists" in which formal schooling is seen as a key institution in modern and/or postmodern society (Boli \& Ramirez, 1990; Meyer, 1977a, 1977b; Meyer, Ramirez, \& Soysol, 1992; Ramirez \& Boli, 1987). ${ }^{2}$ Institutionalism is essentially a theory of culture, but institutionalists recognize the transforming power of a dynamic "world culture" that for better or worse evolved out of Western-style rationality and purposeful action (e.g., Berger, Berger, \& Kellner, 1974). Rationality as a pervasive cultural product (some would say even a hegemonic product) of the historical rise of Western ideas serves to bureaucratize, marketize, individuate, and homogenize the institutions of the world (Finnemore, 1996; Scott \& Meyer, 1994; Thomas et al., 1987). These engaging principles form consistent norms of behavior across a range of modern institutions, thus tying institutions like the modern nation state and formal education together in tight political spheres.

Perhaps the main strength of a global cultural dynamic perspective is that it provides a general overarching theory of where educational change comes from that accounts for both local idiosyncratic histories as well as broad global trends. For example, institutionalism predicts that organizations do not embrace rational operations out of functional objectives like local demands for efficiency. Organizations adopt these operations as a way of adhering to a general culture that legitimates rational bureaucratic forms. Over time, formal education does not make counselors, nurses, or sexual harassment policies mandatory for all schools 
out of functional assessments of the psychiatric, health, and moral needs of each school's students. Instead, these organizational roles are bureaucratically spread as norms derived from a global institutional model of what a modern school must include to be counted as a "legitimate, rationally organized school" (see March \& Olsen, 1976).

Given the degree to which the modern institution of school has penetrated most nations, similar educational processes are repeated in varying degrees around the world, creating considerable international isomorphism in schooling. For example, institutional studies of schooling have shown that curriculum across most nations has become very similar in content and intent over the past 100 years; attendance in public schooling for 10 to 12 years has become the norm in most nations; national governments typically assume a link between mass schooling and national human capital formation; and trends in school administration have become isomorphic globally (Baker \& Holsinger, 1996; Benavot, Cha, Kamens, Meyer, \& Wong, 1991; Fuller \& Rubinson, 1992; Ramirez \& Boli, 1987). Rationality, along with its offshoots of marketization, individualization, bureaucratization, and homogenization, plays the tune that all modern global institutions march to, but it itself is a cultural product and acts as such throughout the social system.

Another strength of this model is that it can account for the existence of important variations in the form of schooling. Significant variations from global institutions occur in some nations, such as Japan. These variations typically devolve from conditions governing the initial borrowing (Dore, 1973; Westney, 1987) or from conflicting institutional rationales or legal conditions (Lincoln, 1990). On the micro-social level a wealth of anthropological studies have documented the ways in which the globalized form of schooling is modified by local cultures (Anderson-Levitt, 1987; Ben-Peretz \& Halkes, 1987; Flinn, 1992; Wolcott, 1967). Flinn, for example, describes this interaction of global institutions and local culture in describing schooling in the Pulap Atoll. Due to traditional forms of deference to male relatives, "female teachers often have to write on the blackboard while sitting on a chair or kneeling on the floor" (p. 51). Yet, nevertheless, the school year, the schedule of holidays, and the curriculum itself are organized around the rationalized model of schooling, which now pervades the world system.

Both national and global dynamic cultural perspectives can be applied to cross-national comparisons of schooling. Both see schools, as well as the main tasks of instruction and the organization of teaching, as a chiefly cultural product. The key difference is that a global dynamic perspective suggests that all local, regional and/or national cultures are responding to a global cultural environment. This shifts the focus from a search for national scripts based on nationally idiosyncratic cultural values for teaching to an assessment of how international forces, such as institutional isomorphism, transform schooling in all societies.

\section{Empirical Illustrations}

We examine these contrasting assumptions about cultural and cross-national comparisons of teaching mathematics with data from the U.S., Japan, and Germany; the latter two being nations with histories that are clearly distinct from that of the U.S. and which are often considered in American policy discussions as international economic and educational competitors. The focus here is on teaching and the organization of the teacher's work as central features of schooling that are often influenced by culture. Although a full assessment of the contrasting assumptions of each perspective is beyond the analytic scope here, it is possible to undertake some revealing analyses. A national culture argument assumes plentiful, distinguishable cross-national variation in the ways teachers organize their instruction, as well as how their work lives at school is organized. By contrast, a global cultural dynamic argument assumes much the opposite and hence predicts considerable isomorphism across nations among these central educational processes.

We use comparable data from both the extensive survey and ethnographic field study on teaching in Germany, Japan, and the U.S. of the 1995 Third International Mathematics and Science Study (TIMSS). The survey data are taken from teachers of nationally representative seventh and eighth grade mathematics classes responding to a host of questions about their instructional practices and the organization of their work in schools. ${ }^{3}$ The qualitative data are taken from the case study component, which is designed to capture local cultural influences on mathematics teachers (i.e., an intensive, field-based study of K-12 schooling in German, Japan, and the U.S. yielding verbatim transcripts of open-ended interviews and classroom observations). ${ }^{4}$ Combining analyses of quantitative and qualitative data allows us to compose a detailed and representative picture of the instructional activities of teachers and their ideas about instruction in these three nations.

\section{Teachers and Their Basic Instructional Assignments}

All schools in mass public systems have teachers, students, principals and a variety of support staff. However, as we look in more detail at the nature of the teaching profession and teachers' daily work, we find some striking differences. Some commonly used indicators of an occupation's level of professional status, such as gender composition, degree of specialization and years of experience, show Germany and Japan to have a more professionalized teacher work force than does the U.S. (see also Lortie, 1975 for a discussion of teacher professionalization). If we compare the backgrounds of mathematics teachers sampled by the TIMSS Population II (U.S. seventh and eighth grade equivalents) in the U.S., Japan, and Germany we find massive gender differences in the workforce. Over $70 \%$ of U.S. math teachers in the TIMSS sample are female, compared to less than $40 \%$ in Germany and only about $20 \%$ in Japan. There are also large differences in the amount of experience accrued by these teaching forces, with the German sample of teachers averaging almost 20 years of teaching.

As shown in Table 1, there are also interesting differences and similarities in the conditions of the job of teacher across the three nations. For Table 1 (and subsequent tables presented in this paper), the percentages in the bottom row of each table are derived from basic one-way analysis of variance (ANOVA) decompositions, where, for each variable, the overall variation among all teachers in the sample is divided into two additive parts: the amount of overall variation attributable to mean differences across 
Table 1

Means in Core Instructional Assignments for Math Teachers of Seventh and Eighth Grade Students

\begin{tabular}{|c|c|c|c|c|c|c|}
\hline \multirow[b]{2}{*}{ Nation } & \multicolumn{2}{|c|}{$\begin{array}{c}\text { Number of } \\
\text { Instructional } \\
\text { Periods Taught } \\
\text { per Week }\end{array}$} & \multicolumn{2}{|c|}{$\begin{array}{c}\text { Number of Grades } \\
\text { Taught in the Current } \\
\text { Year }\end{array}$} & \multicolumn{2}{|c|}{$\begin{array}{c}\text { Percent of Total } \\
\text { Instructional Periods } \\
\text { in Math }\end{array}$} \\
\hline & Mean & $N$ & Mean & $N$ & Mean & $N$ \\
\hline Germany & $20.7^{a b}$ & 174 & $2.4^{\mathrm{ab}}$ & 170 & $57^{\mathrm{ab}}$ & 174 \\
\hline Japan & $16.1^{\mathrm{ac}}$ & 284 & $1.5^{\mathrm{ac}}$ & 284 & $98^{\mathrm{ac}}$ & 284 \\
\hline USA & $18.6^{b c}$ & 378 & $1.6^{\mathrm{bc}}$ & 380 & $89^{b c}$ & 378 \\
\hline $\begin{array}{l}\text { Percentage of } \\
\text { Total Variation } \\
\text { Between Nations }\end{array}$ & \multicolumn{2}{|c|}{$4.1 \%$} & \multicolumn{2}{|c|}{$14.7 \%$} & \multicolumn{2}{|c|}{$40.1 \%$} \\
\hline
\end{tabular}

Source: TIMSS Population II Teacher Survey

a Significantly different than mean for U.S., $\mathrm{p}<.05$.

b Significantly different than mean for Japan, $\mathrm{p}<.05$.

c Significantly different than mean for Germany, $\mathrm{p}<.05$.

d Percentages correspond to the relative size of the between-group component from a between- and within-group ANOVA

decomposition where nations are the groups. Percentages indicate the amount of total variation observed among teachers in all three

nations attributable to differences in national means.

three nations and the amount of overall variation attributable to differences among teachers within nations. The tables report the relative size of only the first component, variation attributable to differences in national means. The percentage of overall variation left unexplained by mean differences across nations can be attributed to variation among teachers within nations.

For example, there is little cross-national difference among the three nations for number of periods of instruction per week (4.1\%). There are some cross-national differences in grade assignments $(14.7 \%)$ and substantial differences in the teaching of mathematics $(40.1 \%)$. German teachers spread their teaching out over more grades. More important is the fact that while nearly $100 \%$ of Japanese math teachers assigned instructional load is in math, American teachers average only $89 \%$ and German teachers only $57 \%$. These findings suggest that some basic parameters of the teaching profession vary significantly across these three nations - differences that suggest there are national cultures of teaching that affect the basic tasks teachers are expected to do.

Although these are basic indicators, they are not superficial; they shed light on what kind of teachers are available for math instruction within a nation. For example, out-of-field teaching has been proposed as one serious problem in U.S. education, limiting the quality of instruction (Ingersoll, 1999, 2000). Japanese math teachers taught virtually all math. On the face of it, this difference would have a profound effect on the quality of instructional and on the way in which teachers conceptualize their role. For instance, if math teachers are teaching many classes in other subjects they will be forced to develop a substantially broader range of teaching, which can in turn lead to lower quality of instruction. Compared to American and German teaching conditions, those of the Japanese math teacher, with relatively few scheduled classes concentrated on mathematics and dis- tributed across a smaller number of grades, suggest a more favorable context in which to focus on math as an intellectual subject.

These survey data show that other pertinent aspects of the work day differ among nations. American teachers have more tightly scheduled weeks than their Japanese or German counterparts. Also, in grades seven and eight, U.S. and German teachers get less common planning time than their Japanese counterparts. For example, $45 \%$ of teachers in Japan reported meeting at least once a week with peers as opposed to $37 \%$ in the U.S. and only $30 \%$ in Germany.

The case study data suggests that differences in planning time have major impacts on what teachers do in the classroom, both in terms of formally scheduled periods and in terms of national variation in planning. For example, German teachers rarely talked about common preparation periods or team meetings with colleagues; instead they tended to socialize during free periods and plan as a group during scheduled subject meetings, as one Gymnasium teacher describes it:

I get to school at 7:30. School starts at 7:40. I teach advanced classes in math first, then I have several free periods in which I chat with colleagues or drive home. I come back to school in the afternoon. It is hard to prepare class here. Even the preparation room is always occupied with people who talk. I cannot concentrate there.

Q: Where and when do you meet colleagues?

A: Since every teacher has different free periods, subject conferences are arranged so that teachers who teach the same subject can meet and exchange ideas and concepts.

Q: How often do you have subject conferences?

A: Usually, we arrange conferences three times during the school term. It's funny but a few colleagues are not even happy having 
those few appointments and leave the conference early. Since they sometimes do not show up, we keep attendee lists.

In contrast, Japanese teachers frequently talked about meeting with other teachers to discuss lessons, planning as individuals, and taking time to study mathematics. The comments of a 32year-old Japanese elementary school teacher, who had recently transferred from middle school, suggest that Japanese teachers are expected to maintain a high level of subject mastery by engaging in collaborative lesson study:

Q: Now, you have come back to elementary. Why do you stay so late [at school]?

A: Here, at elementary . . the Japanese teachers in [this prefecture] have a kind of study/research group.

Q: So each teacher, for example, Mr. K, studies arithmetic, and the other teachers study their specialty?

A: Yes

Although the TIMSS case study data suggest that such teacherorganized subject study is widespread in Japan (Linn, Lewis, Tsuchida, \& Songer, 2000; Lewis \& Tsuchida, 1998; OERI, 1998, pp. 223-236), such organized subject study was rarely reported in the U.S. In all three nations, there is considerable variation in how individual teachers described the organization of their planning time but, on balance, teacher interviews suggest that in the U.S. there is more diversity among teachers than in the other two nations. In some districts American school teachers reported that they are supported by their schools with extensive planning period time, whereas in others teachers reported having no time to plan. At some schools, teachers are inundated with meetings, as one U.S. teacher attests.

Q: Do you have much opportunity to interact with the teachers here?
A: Just with my team. I mean in the department, I guess, interdepartmental meetings, grade levels, we do try to interact on a grade level setting... Usually toward the beginning of the year we all sort of get together and discuss how we will go about teaching the curriculum and then we do have monthly meetings with our math department and since it is just the two member team we have team meetings . . . at least two or three times a week.

Understanding when, how long, and with what purpose teachers meet together about instructional issues is a crucial area for future comparative study. While German and American teachers discussed studying mathematics, they did not refer to the kind of organized study programs that Japanese teachers referred to (Linn et al., 2000, pp. 11-12). Our findings also suggest that most U.S. teachers have little room for flexibility in their weekly schedules. These findings suggest that a teacher's work is constructed along national lines and that these patterns of work assignment are consistent with a national culture perspective.

\section{Teachers' Non-Instructional Assignments}

Moving from instructional load and planning, we see, in Table 2, that while there are statistically significant national differences in formal allocation of teacher duties outside of the classroom, the amount of variation explained by nations is much smaller than that found in comparisons of basic instructional load. For example, teachers in the U.S. reported three times the amount of time assigned to non-instructional supervision of students (6.6 periods) as their Japanese counterparts (2.24 periods) and six times as much as their German counterparts (.15 periods). In contrast, Japanese teachers reported more time on administrative tasks ( 2.43 periods) and counseling students (1.84 periods) and other non-student contact hours than did either their German or U.S. peers.

The case study data, again, support a national culture interpretation. In both the U.S. and Japan, teacher work norms include the expectation that teachers take on some extra duties for

Table 2

Mean Number of Periods Assigned Per Week for Math Teachers of Seventh and Eighth Grade Students

\begin{tabular}{|c|c|c|c|c|c|c|c|c|c|c|}
\hline \multirow[b]{2}{*}{ Nation } & \multicolumn{2}{|c|}{$\begin{array}{c}\text { Supervising } \\
\text { Students }\end{array}$} & \multicolumn{2}{|c|}{$\begin{array}{l}\text { Counseling or } \\
\text { Appraising } \\
\text { Students }\end{array}$} & \multicolumn{2}{|c|}{$\begin{array}{c}\text { Administrative } \\
\text { Tasks }\end{array}$} & \multicolumn{2}{|c|}{$\begin{array}{l}\text { Individual } \\
\text { Planning }\end{array}$} & \multicolumn{2}{|c|}{ Group Planning } \\
\hline & Mean & $N$ & Mean & $N$ & Mean & $N$ & Mean & $N$ & Mean & $N$ \\
\hline Germany & $.15^{\mathrm{ab}}$ & 158 & $.16^{\mathrm{ab}}$ & 156 & $1.13^{\mathrm{ab}}$ & 157 & $.09^{a b}$ & 158 & $.02^{\mathrm{ab}}$ & 158 \\
\hline Japan & $2.24^{\mathrm{ac}}$ & 249 & $1.84^{\mathrm{ac}}$ & 248 & $2.43^{\mathrm{ac}}$ & 248 & $2.49^{c}$ & 250 & $.35^{\mathrm{ac}}$ & 250 \\
\hline USA & $6.60^{b c}$ & 368 & $.63^{\mathrm{bc}}$ & 370 & $.46^{\mathrm{bc}}$ & 367 & $2.88^{\mathrm{c}}$ & 369 & $1.43^{b c}$ & 369 \\
\hline $\begin{array}{l}\text { Percentage of } \\
\text { Total Variation } \\
\text { Between Nations }\end{array}$ & \multicolumn{2}{|c|}{$12.4 \%$} & \multicolumn{2}{|c|}{$11.6 \%$} & \multicolumn{2}{|c|}{$8.6 \%$} & \multicolumn{2}{|c|}{$13.7 \%$} & \multicolumn{2}{|c|}{$11.1 \%$} \\
\hline
\end{tabular}

Source: TIMSS Population II Teacher Survey

a Significantly different than mean for U.S., $\mathrm{p}<.05$.

b Significantly different than mean for Japan, $\mathrm{p}<.05$.

c Significantly different than mean for Germany, $\mathrm{p}<.05$.

d Percentages correspond to the relative size of the between-group component from a between- and within-group ANOVA

decomposition where nations are the groups. Percentages indicate the amount of total variation observed among teachers in all three

nations attributable to differences in national means. 
which they receive nominal or no extra pay. As one U.S. middle schoolteacher reported,

[At] 2:30 we escort the children out, and then at that point, most teachers come back and prepare for the next day. Some teachers like myself have a social center where there is an after school program that goes from 2:40 to 3:40 which for me occurs on Tuesdays to Thursday.

I have pom pom.... teachers [who] have their own after school program and it's just basically to keep the kids off the street, you know to introduce them to something different, there's sewing going on, there's art going on, there's sports going on, there's band, there's a lot of different activities that occur after school for the children.

But, U.S. teachers reported a work week that was significantly influenced by planning for (and adjusting to changes in) nonteaching work. U.S. teachers appear to struggle simply to do all the tasks required of them in a day. One U.S. middle school teacher described her day in this way:

A: OK, well we must be here by seven thirty and I'm usually between seven fifteen and seven thirty, earlier I guess this week because I have duty, cafeteria duty, all this week.

Q: Does that happen very often?

A: Well it does to me for this nine weeks because I do not have an elective, I'm not teaching an elective, whereas the next nine weeks, yes, I will, so I have first and second periods free so I have two planning periods in essence. ... There are several other people who don't and we take care of the normal bus duty or the morning cafeteria duty, excuse me, or for the poor people who are in the ISS teacher [position]. She has no planning, she has no break all day long unless somebody goes in there and stays with her kids so one week ... I would say that every single teacher has some kind of duty at least for a couple of weeks out of the year. That's pretty typical.

Overall, U.S. teachers reported having more periods scheduled to work on supervisory activities than did teachers in Germany or Japan. In Germany, few teachers reported supervisory duties. One teacher, who also played an administrative role, noted that in addition to her main duties of writing lesson plans for substitute teachers, she was also supposed to supervise the school grounds.

Japanese teachers, at least in the middle grades, often have extra supervisory duties, but these assignments tend to be flexible. One male middle school teacher reported letting his colleague pull the "lion's share" of such duties:

Q: Do you supervise a club?

A: Well as for the club, it isn't only me, there is another teacher also supervising it, so if I had to say I'd say I was letting the other teacher do it. So right now club activities don't take much of my time.

One caveat that must be kept in mind is that, over time in all three systems, the teacher's supervisory role changes substantially. Teachers of first graders the world over are responsible for a broader range of children's needs than are teachers of twelfth graders. The data we used focuses on the middle grades when teachers in most systems have to balance serious academic instruction with supervision of student activities that are designed to encourage social development. In this regard, data from the middle grades may exhibit clearer patterns of national difference than that from teachers working among twelfth graders. Nonetheless, at this level the case study data suggest that the supervisory duties reported by most U.S. teachers mean less autonomy to control the flow of work in a given day or week compared to their Japanese or German counterparts.

\section{Instructional Practices}

The publicly released TIMSS video clips of teaching of mathematics in the three nations, as well as summary reports on the videos, support the perspective that teaching is significantly shaped by national culture. In reports on the video study Stigler and Hiebert $(1998,1999)$ adopt a national culture perspective focused on pedagogic practice in Japan as a tool for improvement of pedagogical practice worldwide. Hence their summaries of the video are very sensitive to any differences in instructional practice and attempt to establish the image of a national script for teaching from nation to nation.

Our analysis of what teachers report they do in teaching mathematics suggests that a more complicated perspective is necessary. For example, as shown in Table 3, when we look at a range of core instructional practices, such as using pair work, seatwork, or whole class instruction to instruct students, we find strikingly

\section{American teachers have more tightly scheduled weeks than their Japanese or German counterparts.}

little cross-national variation. Very modest proportions of the total between-teacher variation in teacher instructional practice is due to the nation in which they teach, except for the use of charts (19.9\%). The basic process of teaching in the three nations is very homogenous-evidence of isomorphism that has made actual instruction in classrooms very similar across these nations and perhaps across most others as well.

The findings from the survey data strongly match the conclusions of the International Association for the Evaluation of Educational Achievement classroom environment study in eight nations indicating that what teachers do in the classroom is remarkably similar across nations: "teachers in all countries indicated they used whole class instruction more frequently than small group instruction to review previously taught content. In fact, teachers in all countries reported spending little if any time in small group instruction" (Anderson, Ryan, \& Shapiro, 1989, p. 84).

Contrary to the assumption that national cultures work to produce "unique" patterns of classroom instruction in the U.S., Germany, and Japan, we find significant isomorphism in core instructional practices, at least in terms of relative frequency of use. Here we must interject a caveat. The level of reporting in the survey data is not sufficient to differentiate between different kinds of "groupwork," for example. We do not know if the teachers 
Table 3

Mean Reported Frequency of Use of Specific Instructional Practices for Math Teachers of Seventh and Eighth Grade Students

\begin{tabular}{|c|c|c|c|c|c|c|c|c|c|c|c|c|c|c|}
\hline \multirow[b]{2}{*}{ Nation } & \multicolumn{2}{|c|}{ Seatwork } & \multicolumn{2}{|c|}{$\begin{array}{l}\text { Individual } \\
\text { Guidance }\end{array}$} & \multicolumn{2}{|c|}{ Whole Class } & \multicolumn{2}{|c|}{ Pair Work } & \multicolumn{2}{|c|}{$\begin{array}{l}\text { Explaining } \\
\text { Reasoning }\end{array}$} & \multicolumn{2}{|c|}{$\begin{array}{c}\text { Depict/Use } \\
\text { Charts }\end{array}$} & \multicolumn{2}{|c|}{$\begin{array}{c}\text { Open-Ended } \\
\text { Tasks }\end{array}$} \\
\hline & Mean & $N$ & Mean & $N$ & Mean & $N$ & Mean & $N$ & Mean & $N$ & Mean & $N$ & Mean & $N$ \\
\hline Germany & 1.94 & 163 & $2.60^{b}$ & 163 & $2.78^{\mathrm{ab}}$ & 163 & $1.81^{b}$ & 162 & $2.71^{\mathrm{ab}}$ & 158 & $2.00^{b}$ & 162 & $2.05^{\mathrm{ab}}$ & 163 \\
\hline Japan & 2.07 & 284 & $2.27^{\mathrm{ac}}$ & 279 & $2.99^{\mathrm{ac}}$ & 284 & $1.59^{a c}$ & 284 & $2.92^{\mathrm{c}}$ & 284 & $2.62^{\mathrm{ac}}$ & 283 & $2.18^{\mathrm{ac}}$ & 283 \\
\hline USA & 1.97 & 342 & $2.66^{b}$ & 342 & $2.55^{\mathrm{bc}}$ & 335 & $1.90^{\mathrm{b}}$ & 335 & $2.91^{\mathrm{c}}$ & 339 & $1.95^{b}$ & 338 & $1.83^{\mathrm{bc}}$ & 338 \\
\hline $\begin{array}{l}\text { Percentage of } \\
\text { Total Variation } \\
\text { Between Nations }\end{array}$ & \multicolumn{2}{|c|}{$0.6 \%$} & \multicolumn{2}{|c|}{$7.4 \%$} & \multicolumn{2}{|c|}{$7.0 \%$} & \multicolumn{2}{|c|}{$4.5 \%$} & \multicolumn{2}{|c|}{$1.2 \%$} & \multicolumn{2}{|c|}{$19.9 \%$} & \multicolumn{2}{|c|}{$7.2 \%$} \\
\hline
\end{tabular}

$1=$ "never or almost never" . . 4 = "every lesson"

Source: TIMSS Population II Teacher Survey

a Significantly different than mean for U.S., $\mathrm{p}<.05$.

b Significantly different than mean for Japan, $\mathrm{p}<.05$

c Significantly different than mean for Germany, $\mathrm{p}<.05$.

d Percentages correspond to the relative size of the between-group component from a between- and within-group ANOVA

decomposition where nations are the groups. Percentages indicate the amount of total variation observed among teachers in all three nations attributable to differences in national means.

were using heterogeneous or homogenous ability groups, nor what task the groups were given. Thus, while these data indicate that math teachers in the three countries use basic instructional practices for relatively the same proportion of time, the data do not allow a more fine-grained analysis of how each practice is enacted. If we simply look at the overall frequency of basic instructional practices that mathematics teachers use, then Japanese, German, and U.S. teachers all appear to be working from a very similar "cultural script," which is exactly what proponents of institutional isomorphism would predict.

So far, our empirical illustration appears to support both perspectives, albeit at different levels. Teachers work in organizations where the contours of the work day and work week are influenced by national variation in educational labor arrangements and some cultural expectations for the role of teacher. At the same time, teachers work inside classrooms where the basic instructional processes appear to have undergone significant crossnational isomorphism. Apparently, teachers may be affected by different sets of institutional rationales. Another way to assess the relative impact of these two perspectives is to examine how mathematics teachers think about their jobs.

\section{Beliefs About Teaching Math}

A national culture perspective would suggest that teacher perceptions and beliefs about math and teaching would be an important factor affecting how teachers use certain instructional practices (cf. Stigler \& Hiebert, 1998), whereas a global cultural dynamic perspective would predict that teachers beliefs and practices would be affected by the globalized, rational account of the school (cf. Meyer, 1977b). Some previous studies support a national culture perspective, for example: Japanese teachers tend to discount large innate differences in intelligence, or capacity for learning, and vigorously oppose tracking at the elementary and middle school level (OERI, 1998, p. 41). Stigler and Hiebert (1999, p. 94) also state that Japanese teachers view "individual differences" in the math classroom "as a natural characteristic of the group" and as "a resource for both students and teachers." This interpretation is consistent with previous research in this area (Lee, Graham, \& Stevenson, 1996; Stigler, Fernandez, \& Yoshida, 1996).

However, in the TIMSS survey, when teachers were asked to agree to various sets of statements, such as "some students have a natural talent for mathematics and others do not," we find similar percentages of Japanese and U.S. mathematics teachers disagreeing with this statement (28\% for Japanese and $21 \%$ for U.S. teachers) whereas only about $11 \%$ of German teachers disagree. The responses to this single question do not invalidate the notion that Japanese teachers in general have a strong ideal that individual differences should not be a factor in affecting mathematics achievement. They do show, however, that teacher beliefs are far more complex than previous images of national cultural scripts for teaching would suggest.

As shown in Table 4, there is considerable cross-national similarity in how teachers think about obstacles and resources in teaching mathematics. There was little cross-national variation in teacher beliefs about the limits placed on learning due to qualities of students (different abilities, $2.7 \%$, lack of motivation, $1.0 \%$, parent's interests, $1.8 \%$ ) or even the student-teacher ratio $(1.8 \%)$.

This lack of substantial cross-national differences among teacher's beliefs about differing student abilities is of particular interest when contrasted with the recent discussions in the U.S. about how Japanese find individual differences to be helpful to their instructional practices (Stigler \& Hiebert, 1999). ${ }^{5}$ In the present sample, Japanese math teachers see "students with different academic abilities" as slightly more of an obstacle in teaching (2.75) than their German (2.55) and U.S. (2.48) counterparts. 
Table 4

Mean Perceptions About What Limits Teaching in Math for Math Teachers of Seventh and Eighth Grade Students

\begin{tabular}{|c|c|c|c|c|c|c|c|c|c|c|}
\hline \multirow[b]{2}{*}{ Nation } & \multicolumn{2}{|c|}{$\begin{array}{l}\text { Different } \\
\text { Abilities }\end{array}$} & \multicolumn{2}{|c|}{$\begin{array}{l}\text { Uninterested } \\
\text { Students }\end{array}$} & \multicolumn{2}{|c|}{ Parent Interest } & \multicolumn{2}{|c|}{$\begin{array}{l}\text { Computer } \\
\text { Shortage }\end{array}$} & \multicolumn{2}{|c|}{$\begin{array}{c}\text { Teacher } \\
\text { Student Ratio }\end{array}$} \\
\hline & Mean & $N$ & Mean & $N$ & Mean & $N$ & Mean & $N$ & Mean & $N$ \\
\hline Germany & $2.55^{b}$ & 163 & 2.47 & 163 & $1.37^{a}$ & 163 & $1.32^{\mathrm{a}}$ & 162 & $2.02^{b}$ & 163 \\
\hline Japan & $2.75^{\mathrm{ac}}$ & 284 & $2.38^{\mathrm{a}}$ & 284 & $2.36^{\mathrm{a}}$ & 283 & $1.44^{\mathrm{a}}$ & 283 & $2.34^{\mathrm{ac}}$ & 283 \\
\hline USA & $2.48^{\mathrm{b}}$ & 339 & $2.57^{b}$ & 339 & $1.56^{\mathrm{bc}}$ & 336 & $2.06^{\mathrm{bc}}$ & 338 & $2.07^{b}$ & 338 \\
\hline $\begin{array}{l}\text { Percentage of } \\
\text { Total Variation } \\
\text { Between Nations }\end{array}$ & \multicolumn{2}{|c|}{$2.7 \%$} & \multicolumn{2}{|c|}{$1.0 \%$} & \multicolumn{2}{|c|}{$1.8 \%$} & \multicolumn{2}{|c|}{$13.9 \%$} & \multicolumn{2}{|c|}{$1.8 \%$} \\
\hline
\end{tabular}

Reported Degree of Impact (1 = "not at all" . . . 4 = "a great deal").

Source: TIMSS Population II Teacher Survey

a Significantly different than mean for U.S., $\mathrm{p}<.05$.

b Significantly different than mean for Japan, $\mathrm{p}<.05$.

c Significantly different than mean for Germany, $\mathrm{p}<.05$.

d Percentages correspond to the relative size of the between-group component from a between- and within-group ANOVA

decomposition where nations are the groups. Percentages indicate the amount of total variation observed among teachers in all three

nations attributable to differences in national means.

While Japanese teachers in general may believe it is best to concentrate on student effort rather than ability, the case study data (OERI, 1998, p. 84) show that Japanese have several indigenous terms for labeling individual ability differences (e.g., saino, talent or giftedness; soshitsu, innate abilities or gifts). One Japanese teacher listed four elements in individual ability differences that are recognized by many Japanese teachers: (1) genetic disposition, (2) education and support from parents, (3) classroom environment and atmosphere, (4) acknowledgment in school.

This evidence of a substantial range of variation in teacher beliefs within a nation, combined with similar average beliefs across these nations on questions about what teachers believe limits teaching and learning, presents serious questions about the assumption that cross-national differences in beliefs or values held by teachers are the root of major cross-national differences in instructional approaches. Finally, as Table 5 illustrates, the teachers in this sample display remarkable cross-national isomorphism on a wide range of beliefs about how mathematics is learned. In this empirical illustration there is virtually no cross-national variation in perceptions of fundamental learning processes (with the exception of a modest differences in the use of practice as an important aspect of learning, 14.0\%). Again, such evidence makes it hard to assume that differences in mathematics teaching are a direct result of cross-national differences in the beliefs and attitudes that teachers have towards teaching or learning.

These five variables represent a small sample of the total available in the TIMSS data set. We must exert caution in overinterpeting these results, and of course we only present here the simple, bi-variate analyses. There is always the possibility that more complex multivariate modeling might uncover a different cross-national pattern, although we suspect that this is unlikely. And even in these analyses mean national differences, when found, are not always in the direction predicted by scholars who adopt a national culture argument. For example, Japanese teach- ers emphasized thinking creatively in math more than U.S. teachers did, but U.S. teachers were more likely to emphasize understanding mathematical concepts and understanding realworld usage- beliefs one would assume to be more characteristic of Japanese teachers who have been shown to spend much time on concept development and application of concepts, at least in science classes (Linn, Lewis, Tsuchida, \& Songer, 2000).

Indeed, looking for a pattern of global agreement about key ideas is more fruitful than looking for a pattern of national differences. In analyzing the wider range of TIMSS Population II variables not presented here, we found that German, Japanese, and U.S. math teachers in the TIMSS rank "students with different academic abilities" and "uninterested students" as far more of a challenge to their teaching than the other factors presented to them in the survey. These teachers also agree that using multiple representations in teaching math as well as a liking and understanding of students are more important to math learning than just teaching basic computational skills.

Turning back to the case study data, which on the surface suggest strong national cultures, we find that Japanese classroom instruction in the middle grades is influenced by the high school entrance examination system. Since most teachers wish to send as many students as possible to the best high school in the community, they closely follow the national curriculum on which the public high school entrance examinations are based. Japanese teachers feel responsible to give all classes the same opportunity to succeed on the exam. Teachers believe there are individual ability differences, but they also believe that there are individual differences in effort, and in balancing the equation of effort and ability, teachers tend to favor ability. When asked about ability grouping in class, one Japanese teacher responded: "I don't think that's acceptable. I don't think it's a very democratic way of handing the situation."

Most Japanese teachers recognize that effort is an essential ingredient in developing these gifts and tend to emphasize effort in 
Table 5

Mean Beliefs About Learning Math for Math Teachers of Seventh and Eighth Grade Students

\begin{tabular}{|c|c|c|c|c|c|c|c|c|c|c|}
\hline \multirow[b]{2}{*}{ Nation } & \multicolumn{2}{|c|}{$\begin{array}{c}\text { Math is } \\
\text { Primarily an } \\
\text { Abstract } \\
\text { Subject }\end{array}$} & \multicolumn{2}{|c|}{$\begin{array}{c}\text { Math is } \\
\text { Primarily for } \\
\text { Addressing } \\
\text { Real Situations }\end{array}$} & \multicolumn{2}{|c|}{$\begin{array}{c}\text { If Students } \\
\text { Have } \\
\text { Difficulty Give } \\
\text { More Practice }\end{array}$} & \multicolumn{2}{|c|}{$\begin{array}{c}\text { Some } \\
\text { Students Have } \\
\text { Natural Talent }\end{array}$} & \multicolumn{2}{|c|}{$\begin{array}{l}\text { Liking } \\
\text { Students is } \\
\text { Essential for } \\
\text { Teaching }\end{array}$} \\
\hline & Mean & $N$ & Mean & $N$ & Mean & $N$ & Mean & $N$ & Mean & $N$ \\
\hline Germany & $2.23^{b}$ & 167 & $2.83^{a}$ & 164 & $2.79^{a b}$ & 167 & $3.06^{\mathrm{ab}}$ & 167 & $3.20^{\mathrm{ab}}$ & 167 \\
\hline Japan & $2.62^{\mathrm{ac}}$ & 283 & $2.92^{\mathrm{a}}$ & 281 & $2.20^{\mathrm{ac}}$ & 283 & $2.78^{\mathrm{ac}}$ & 281 & $3.43^{c}$ & 281 \\
\hline USA & $2.17^{b}$ & 360 & $3.11^{b}$ & 358 & $2.06^{b c}$ & 360 & $2.89^{b c}$ & 359 & $3.48^{c}$ & 358 \\
\hline $\begin{array}{l}\text { Percentage of } \\
\text { Total Variation } \\
\text { Between Nations }\end{array}$ & \multicolumn{2}{|c|}{$8.6 \%$} & \multicolumn{2}{|c|}{$4.3 \%$} & \multicolumn{2}{|c|}{$14.0 \%$} & \multicolumn{2}{|c|}{$2.4 \%$} & \multicolumn{2}{|c|}{$3.0 \%$} \\
\hline
\end{tabular}

Reported Degree of Importance (1 = "strongly disagree" . . 4 = "strongly agree").

Source: TIMSS Population II Teacher Survey

a Significantly different than mean for U.S., $\mathrm{p}<.05$.

b Significantly different than mean for Japan, $\mathrm{p}<.05$.

c Significantly different than mean for Germany, $\mathrm{p}<.05$.

d Percentages correspond to the relative size of the between-group component from a between- and within-group ANOVA

decomposition where nations are the groups. Percentages indicate the amount of total variation observed among teachers in all three

nations attributable to differences in national means.

a way that most U.S. teachers do not, yet Japanese teachers recognize individual differences and the consequences of those differences will have on the important high school entrance exam. Perhaps Japanese teachers find themselves in a quandary when faced with multiple-ability levels in the same classroom: Do I spend more time on the "slower" students or pump up the "fast" ones? The following exchange between a TIMSS researcher and a middle school science teacher in Japan clearly demonstrates the conflicts Japanese teachers face:

Q: Do you divide your students into groups according to ability?

A: No, I don't do that. In Japan, that will never work positively because students would feel ashamed.

Q: Are you, then, doing anything special to cope with individual differences?

A: I give them houshuu [extra practice]. I first give them a hand out on a certain lesson, and tell them that if they don't understand, they could attend hoshuu after school.

Q: To/for what level of students are you giving hoshuu?

A: I am hoping that the students who are below average would come to hoshuu. Those who do well can solve problems on their own. So hoshuu is aimed at the students who are having a hard time trying to find out the way to solve problems. But we cannot provide hoshuu everyday, so I know it isn't enough.

This Japanese teacher faces a dilemma. Partly the dilemma arises from contradictions between cultural ideals; partly it arises from the working conditions of teachers in modern, democratic nations. This teacher's dilemma will be immediately familiar to most U.S. educators. Despite the cultural and historical differences between the U.S., Germany and Japan, teachers in these three nations often face very similar conditions or problems. The problem of providing adequate instruction to a class consisting of students with heterogeneous ability levels is not determined, or solved by, cultural beliefs. All over the world, not just in the U.S., Germany, or Japan, educators face significant problems in trying to provide equal access to the curriculum for all while simultaneously working to maximize each student's individual potential.

\section{Culture and Institutional Context of Teaching: Nationally Bound or Globally Dynamic?}

The illustrative analysis presented here shows that in these three nations globally transmitted institutions play a key role in determining instructional practice and teacher beliefs. Both for anthropologists such as Spindler (1977/1984) and for sociologists such as Zucker (1977), socio-cultural change and cultural persistence in the modern world system centers on institutionalized organizational forms (i.e., the institution of hospitals or schools as opposed to the specific organizational reality of the local hospital or school). As Douglas (1986, p. 46) wrote, "established institutions, if challenged, are able to rest their claims to legitimacy on their fit with the nature of the universe." The overall "charter" of the modern school is in large part a global one (cf. Meyer, 1977a).

Teachers in modern nations such as Japan, Germany, and the U.S. go about their jobs in highly institutionalized social settings where their identities are shaped by the existing institution and where the patterns of their work are driven by the rules and procedures of the specific school (organization) in which they work and the larger institution of schooling. Institutions "channel our perceptions into forms compatible with the relations they authorize" (Douglas, 1986, p. 92). While this is true, it would be inaccurate to suggest that our analysis shows no national differences. What has been overlooked in cross-national comparisons of teaching is how teachers are simultaneously affected by at least three cul- 
tural levels: (1) a global institutional form of schooling; (2) national or regional laws that affect the organization of schools; and (3) national, regional, or local systems, customs and expectations.

While there are undeniable national cultural factors that affect teaching in the U.S. and other nations, an overemphasis on the effect of the general "culture" or cultural ideals within a given nation leads to studies that downplay how global dynamics in national educational policy and school organization affect teachers' working lives. The global isomorphism of schooling that has occurred in the last century is a process that creates similar predicaments for teachers. Classroom environments are remarkably similar around the world, and teachers must work within rather homogenous parameters of instructional practice that are institutionalized on a global level.

National cultural arguments tend to reify a view of culture as roughly defined as the language, value, and beliefs of a given group of people. This view of culture misses two major trends in cultural theory: (1) that culture is a dynamic process and that socialization into national or regional cultures is uneven, and (2) that all modern nations have "cultures" that are significantly influenced by the rationalization of society and spread of institutions that has taken place over the last century. Much of the "culture" of nations like Japan, the U.S., and Germany is embedded in shared common institutional forms establishing similar organizational patterns based on a single overarching model, e.g., the hospital, the school, the legislature, and the corporation.

There is good empirical evidence to show that in some cases national cultures can alter global institutional forms as they enter a country (e.g., Westney, 1987) just as there is evidence that a nation's legal code can create diverse, national institutional variants. The idea that teaching is primarily a cultural activity, or that a whole nation of teachers follow what some have called a "national script" for teaching, glosses over the fact that a variety of individuals and organizations make rules, policies, and laws that significantly affect the way teachers organize their day and that these individuals and organizations are affected by changes in the world in general.

In terms of the instructional core of teaching mathematics (e.g., basic classroom), teachers are clearly very similar in the U.S., Japan, and Germany, as their work is conducted in schools that have undergone a process of global isomorphism over the last 100 years. The fact that individual teachers' perceptions and beliefs are strikingly similar cross-nationally suggests that teachers' reports of how they view the act of teaching mathematics and the nature of this subject may be more influenced by the global institution of schooling than by national culture.

Yet in terms of the broader role of the teacher (the total range of duties, services, or responsibilities teachers are expected to fulfill) national cultures still have an influence. As we noted above, these basic differences in overall teacher work patterns may have significant impacts on the specific enactment of core instructional practices in the classroom. The fact that Japanese teachers teach comparatively few periods, specialize in math, and have ample planning time makes possible the kind of elaborate lesson planning documented by Lewis and Tsuchida (1998) and might encourage Japanese math teachers to focus more on mathematical reasoning as opposed to memorizing concepts.

\section{Culture and International Data:}

Assumptions for Policy Making

We began by noting the extensive use of comparative data from different nations in U.S. policy debates and the accompanying use of contrasting, yet often unspecified, assumptions about culture and its role in the creation of cross-national differences. After our brief assessment of these assumptions about culture, what lessons are there for the incorporation of cross-national data into policy formation?

Neither our results nor our reading of the supporting literature on culture and education suggest that there is an "either or" conclusion to be made between these two views of culture and education. Both notions of culture-a dynamic global institutional one and a national one (as well as regional and local ones) - have some merit from which to consider cross-national data for use in policy discussions. But the results here, particularly those on the extreme degree of isomorphism of core instructional practices and teacher beliefs, offer some important caveats to the entire enterprise of extensive use of national cultural images to incorporate intentional information into discussions about educational reform in the U.S.

A general national culture perspective has been the popular view applied to these kinds of data. People seem to like to think this way. Other nations seem exotic from afar and the image that their institutions run in very different ways from familiar ones at home is easy to seize upon. Indeed, most nations-states rely heavily on myths of self-contained or autochthonous cultures to legitimate their existence (see Anderson 1991). But our results presented here suggest a real danger in taking a national cultural image too far. The concept of a "national script" for teaching is an amalgam of cultural ideals about what should happen in an ideal lesson in this nation, not what actually occurs.

Idealized images of the perfect instructional activity, as every teacher knows, rarely materialize in the classroom. Not only does each class of students present a unique social situation; teachers themselves vary in their stated ideals. And, if there are general beliefs about the ideal role of the teacher (or expectations for how teachers "should" behave) that are unique to a modern U.S., Japan, or Germany, these must be expressed in institutional forms (schools) that are largely derived from the same Western notion about the institution of schooling.

Over time, local accommodations and adaptations occur in all nations both in terms of individuals conforming to ideals transmitted via a global institutional form as well as modifications individuals make in how they enact their institutional role within a specific organization. Cross-national idealization of other nations misses these two processes; it assumes them away and is therefore a particularly problematic image for realistic policy discussions about cross-national data.

A related problem with too much reliance on an image of national cultures is the slippery slope of "selecting on the dependent variable" in the use of cross-national data. All too often it is easy to start an analysis of this kind of data by thinking, if nation $\mathrm{X}$ outperforms nation $\mathrm{Y}$ in achievement, then any and all differences between them are possible causes of this differences. The salient features of schooling in nation X soon become celebrated as causes of superior performance, and hence unusual educational features in nations like Japan and Singapore take on untested 
prominence in policy debates about improving education in other nations like the U.S. Research suggests that lessons in Japanese middle grades elementary and math classrooms "flow like a river," that there is a swift, connected stream of material moves at a brisk pace (Linn, Lewis, Tsuchida, \& Songer, 2000). In contrast, some have described the U.S. curriculum as a river that is "a mile wide and an inch deep," a metaphor that implies lessons cannot move in a brisk, connected way (Schmidt, McKnight, \& Raizen, 1997). Debates about such differences often invoke cultural differences between "Asian" and "Western" attitudes toward education, but these cultural ideas are rarely if ever tested, yet they become part of the lexicon of international comparisons, accepted and assumed to be true.

This is not to say that cross-national data are not useful or that nations do not have different, interesting, and potentially useful ways of organizing schooling, teachers, and teaching. They clearly do, and wise use of cross-national information can be very enlightening to policy discussion. Our caution is that the unspecified assumptions inherent in an image of national cultures leads to too much idealization and celebration of national differences without clear thought on what these differences may really mean for exportation of better educational approaches.

Similarly it is dangerous to imply that a global dynamic culture pushes everything everywhere to be the same at all times. Empirically this is not true and conceptually it leads to a theoretical dead end where unique national and local change is impossible. However, the forces behind global institutional isomorphism are considerable and failing to recognize their power in all organizations within the same institutional sector everywhere in the world is a route to an unclear picture of how culture actually works in a dynamic fashion. Cross-national studies of teaching need to consider and theorize as much about isomorphic processes as they currently do about national processes. The challenge for future cross-national research, and its use in policymaking, is to continue to push our theoretical models of culture and the educational process to reflect more accurately the complex empirical reality of the classrooms around the world.

\section{NOTES}

This research stems from a project entitled "Analyses and Augmentation of TIMSS Data," joint grant from the Department of Education, Fund for the Improvement of Education, \#5-33018-A; National Science Foundation, 5-33485-A.

${ }^{1}$ Also, see the articles in Anthropology and Education Quarterly 23,(1), 1992.

${ }^{2}$ For brevity we refer to this theory as institutionalism even though sometimes a distinction is drawn between the "new" institutionalism of these theorists and an older sociological version of the role of institutions in society.

${ }^{3}$ See Martin and Mullis (1996) or Beaton et al. (1996) for details regarding sampling, data collection and quality assurance.

${ }^{4}$ See Stevenson \& Nerison-Low (2000) for details regarding sampling, data collection and quality assurance.

${ }^{5}$ For example, note the usual assumptions about differing Asian and Western cultures of schooling in arguments that do not necessarily embrace the popular positive image of Japanese education in Bracey (1997).

\section{REFERENCES}

Anderson, B. (1991). Imagined communities: Reflections on the origin and spread of nationalism. New York: Verso.
Anderson, L., Ryan, D., \& Shapiro, B. (1989). The IEA classroom environment study. New York: Pergamon Press.

Anderson-Levitt, K. (1987). National culture and teaching culture. Anthropology \& Education Quarterly, 18, 33-37.

Baker, D. (2001). TIMSS-R: Innovation international information for American educators. Education Statistics Quarterly, 3(1), 17-19. National Center for Education Statistics, U.S. Department of Education.

Baker, D., \& Holsinger, D. (1996). Human capital formation and school expansion in Asia: Does a unique regional model Exist?" International Journal of Comparative Sociology, 37, 159-173.

Baker, D., \& LeTendre, G. (2000). Comparative sociology of classroom processes, school organization, and achievement. In M. Hallinan (Ed.), Handbook of the Sociology of Education (pp. 345-364). New York: Kluwer.

Beaton, A., Mullis, I., Martin, M., Gonzalez, E., Kelly, D., \& Smith, T. (1996). Mathematics Achievement in the Middle School Years: IEA's Third International Mathematics and Science Study (TIMSS). Chestnut Hill, MA: Boston College, Center for the Study of Testing, Evaluation, and Educational Policy.

Ben-Peretz, M., \& Halkes, R. (1987). How teachers know their classrooms: A cross-cultural study of teachers' understandings of classroom situations. Anthropology \& Education Quarterly, 18, 17-32.

Benavot, A., Cha, Y-K., Kamens, D., Meyer, J., \& Wong, S-Y. (1991). Knowledge for the masses: World models and national curricula, 1920-1986. American Sociological Review, 56, 85-100.

Bennett, W. (1987). "Looking at Japanese Education: Implications for American Education." NASSP Bulletin 71(499): 102-108.

Berger, P. L., Berger, B, \& Kellner, H. (1974). The homeless mind. New York: Random House.

Berliner, D., \& Biddle, B. (1995). The manufactured crisis. New York: Addison-Wesley Publishing Company.

Boli, J., \& Meyer, J. (1987). The ideology of childhood and the state: Rules distinguishing children in national constitutions, 1870-1970. In G. Thomas, J. Meyer, F. Ramirez, \& J. Boli (Eds.), Institutional instruction (pp. 217-241). Beverly Hills: Sage Publications.

Boli, J. and F. Ramirez (1990). Compulsory schooling in the western cultural context:Essence and variation. Emergent Issues in Education: Comparative Perspectives. R. Arnove, P. Altbach and G. Kelly.

Bracey, G. (1997). On comparing the incomparable: A response to Baker and Stedman. Educational Researcher, 26(3), 19-26.

Comaroff, J., \& Comaroff, J. (1992). Ethnography and the historical imagination. Boulder, CO: Westview Press.

Cummings, W. (1995). The Asian human resource approach in global perspective. Oxford Review of Education, 21(1), 67-81.

Cummings, W. K. (1980). Education and equality in Japan. Princeton, Princeton University Press.

Dimaggio, P. and W. Powell (1991). The new institutionalism in organizational analysis. Chicago, University of Chicago Press.

Dore, R. (1973). British factory — Japanese factory. Berkeley: University of California Press.

Douglas, M. (1986). How institutions think. Syracuse, NY: Syracuse University Press.

Finn, C. (1992). More like them. The Public Interest, 107(Spring), 106-112.

Finnemore, M. (1996). Norms, culture, and world politics: Insights from sociology's institutionalism. International Organization, 50(2), 325-47.

Flinn, J. (1992). Transmitting traditional values in new schools: Elementary education of Pulap Atoll. Anthropology \& Education Quarterly 23, $44-58$.

Fuller, B., \& Rubinson, R. (Eds.). (1992). The political construction of education: The state, school expansion, and economic change. New York: Praeger.

Goya, S. (1993). The secret of Japanese education. Phi Delta Kappan, 75(2), 126-129. 
Hendry, J. (1986). Becoming Japanese: The world of the pre-school child. Manchester, United Kingdom: Manchester University Press.

Ingersoll, R. (1999). The problem of underqualified teachers in American secondary schools. Educational Researcher, 28(2), 26-37.

Ingersoll, R. (2001). Rejoinder: Misunderstanding the problem of outof-field teaching. Educational Researcher, 30(1), 21-22.

Kinney, C. (1997-1998). Building an excellent teacher corps: How Japan does it. American Educator, 21(4), 16-23.

Lee, S-Y., Graham, T., \& Stevenson, H. (1996). Teachers and teaching: Elementary schools in Japan and the United States. In T. Rohlen, \& G. LeTendre (Eds.), Teaching and learning in Japan (pp. 157-189). New York: Cambridge University Press.

LeTendre, G. (Ed.). (1999a). Competitor or ally. New York: Falmer.

LeTendre, G. (1999b). The problem of Japan: Qualitative studies and international educational comparisons. Educational Researcher, 28(2), 38-48.

LeTendre, G. (2000). Learning to be adolescent: Growing up in U.S. and Japanese middle schools. New Haven, CT: Yale University Press.

LeTendre, G. and D. Baker (1999). International Comparisons and Educational Research Policy. Competitor or Ally? G. LeTendre. New York, Falmer Press: 123-140.

Lewis, C. (1995). Educating hearts and minds. New York: Cambridge University Press.

Lewis, C., \& Tsuchida, I. (1998). A lesson is like a swiftly flowing river. American Educator, 22(4), 12-17.

Lincoln, J. (1990). Japanese organization and organization theory. Research in Organizational Behavior, 12, 255-294.

Linn, M., Lewis, C., Tsuchida, I., \& Songer, N. (2000). Beyond fourthgrade science: Why do U.S. and Japanese students diverge? Educational Research, 29(3), 4-14.

Lortie, D. C. (1975). Schoolteacher: A sociological study. University of Chicago Press.

March J., \& Olsen, J. (1976). Ambiguity and choice in organizations. Begen: Universietsforlaget.

Martin, M., \& Mullis, I. (1996). Third International Mathematics and Science Study: Quality Assurance in Data Collection. Boston College: Center for the Study of Testing, Evaluation, and Educational Policy.

Meyer, J. (1977a). The world educational revolution, 1950-1970. Sociology of Education, 250, 242-258.

Meyer, J. (1977b). The effects of education as an institution. American Journal of Sociology, 83, 55-77.

Meyer, J., Ramirez, F., \& Soysol, Y. (1992). World expansion of mass education, 1870-1980. Sociology of Education, 65(2), 148-159.

Office of Educational Research and Improvement (OERI). (1998). The educational system in Japan: Case study findings (pp. 41, 218-236). Washington, DC: U.S. Department of Education.

Peak, L. (1991). Learning to go to school in Japan. Berkeley: University of California Press.

\section{BOOK REVIEW SUBMISSIONS} Starting January 2002, the Book Review section of Educational Researcher will have a new editorial team: Michele Foster and Vernon Polite.

Starting now, please send book review manuscripts to

Michele Foster

25 Standish Court

Crockett, CA 94525

michelf9@icdc.com
Ramirez, F., \& Boli, J. (1987). Global patterns of educational institutionalization. In G. Thomas, J. Meyer, F. Ramirez, \& J. Boli (Eds.), Institutional instruction (pp. 150-172). Beverly Hills: Sage Publications.

Ravitch, D. (1986). Japan's smart schools. The New Republic, 194, 13-15.

Rohlen, T., \& LeTendre, G. (1996). Teaching and learning in Japan. New York: Cambridge University Press.

Schmidt, W., McKnight, C., \& Raizen, S. (1997). A splintered vision: An investigation of U.S. science and mathematics education. London: Kluwer Academic Publishers.

Scott, W. R., \& Meyer, J. (Eds.). (1994). Institutional environment and organizations: Structural complexity and individualism. Thousand Oaks CA: Sage Publications.

Spindler, G. D., \& Spindler, L. (1987a). Cultural dialogue and schooling in Schoenhausen and Roseville: A comparative analysis. Anthropology and Education Quarterly, 18(1), 1-16.

Spindler, G. D., \& Spindler, L. (1987b). Schoenhausen revisited and the rediscovery of culture. In G. D. Spindler \& L. Spindler (Eds.), Intrepretive ethnography of education (pp. 143-167). Hillsdale, NJ: Lawrence Erlbaum.

Spindler, G., Spindler, L., Trueba, H., \& Williams, M. (1990). The American cultural dialogue and its transmission. New York: Falmer Press.

Spindler, L. S. (1984). Culture change and modernization: Mini-models and case studies. Prospect Heights, IL: Waveland Press. (original work published in 1977)

Stevenson, H., H. Azuma, et al., Eds. (1986). Child Development and Education in Japan. New York: W. H. Freemand and Company.

Stevenson, H., \& Nerison-Low, R. (2000). To sum it up: TIMSS case studies of education in Germany, Japan and the United States. Philadelphia, PA: Mid-Atlantic Eisenhower Consortium for Mathematics and Science Education.

Stevenson, H., \& Stigler, J. (1992). The learning gap. New York: Summit Books.

Stigler, J., Fernandez, C., \& Yoshida, M. (1996). Cultures of mathematics instruction in Japanese and American elementary classrooms. In T. Rohlen \& G. LeTendre (Eds.), Teaching and learning in Japan (pp. 157-189). New York: Cambridge University Press.

Stigler, J., \& Hiebert, J. (1998). Teaching is a cultural activity. American Educator, 22(4), 4-11.

Stigler, J., \& Hiebert, J. (1999). The learning gap: Best ideas from the world's teachers for improving education in the classroom. New York: Free Press.

Stigler, J., \& Stevenson, H. (1991). How Asian teachers polish each lesson to perfection. American Educator, 15(1), 12-20.

Storey, E. P., \& Sisson, K. (1997). Managers in the making: Careers, development and control in corporate Britain and Japan. London: Sage.

Thomas, G., Meyer, J., et al., Eds. (1987). Institutional Structure. Beverly Hills, CA, Sage Publications.

Tobin, J., Wu, J., \& Davidson, D. (1989). Preschools in three cultures: Japan, China and the United States. New Haven, CT: Yale University Press.

Torney-Purta, J. (1987). The Role of Comparative Education in the Debate on Excellence. Education and Social Concern: An Approach to Social Foundations. R. Lawson, V. Rust and S. Shafer. Ann Arbor, MI, Prakken Publications.

Westney, D. (1987). Imitation and innovation: The transfer of western organizational patterns to Meiji Japan. Cambridge: Harvard University Press.

Wolcott, H. (1967). A Kwakiutl village and school. Prospect Heights, IL: Waveland Press, Inc.

Wolf, M. (1992). A thrice-told tale: Feminism, postmodernism and ethnographic responsibility. Stanford, CA: Stanford University Press.

Zucker, L. (1977). The role of institutionalization in cultural persistence. American Sociological Review 42, 726-743. 


\section{AUTHORS}

GERALD K. LETENDRE is a professor in the Department of Education Policy Studies at Pennsylvania State University, University Park, PA 18602; gkl103@psu.edu. His research interests include adolescent decision making and school organization.

DAVID P. BAKER is a professor in the Departments of Education Policy Studies and Sociology at Pennsylvania State University, University Park, PA 18602; dpb4@psu.edu. His research interests include the comparative analysis of the institutionalization of education in society.

MOTOKO AKIBA is a senior researcher at Mills College, 5000 MacArthur Blvd., Oakland, CA 94613; makiba@mills.edu. His research interests include school violence and lesson-study.

BRIAN GOESLING is a doctoral candidate in the Department of Sociology at Pennsylvania State University, University Park, PA 18602; goesling@pop.psu.edu. His research interests include social stratification and institutional theory.

ALEX WISEMAN is a doctoral candidate in the Department of Education Policy Studies at Pennsylvania State University, University Park, PA 18602; aww112@psu.edu. His research interests include the mangerial activity of principals, school-to-work transition, and comparative analysis of educational systems.

Manuscript received November 14, 2000 Final revision received June 14, 200 I Accepted June 14, 200 I
The Teachers College Record

is stepping up production...

...With its ALL-NEW

ONLINE VERSION

www.tcrecord.org

Visit us for:

The latest developments in educational research published online weekly

The most complete coverage of opportunites for publishing your work in journals and books

$\boldsymbol{A}$ new section on tools and tutorials to aid educational researchers

Discussions on major topics in education and educational research

Full-text articles from the TCRecord TCRecord.org print journal

The voice of scholarship in education

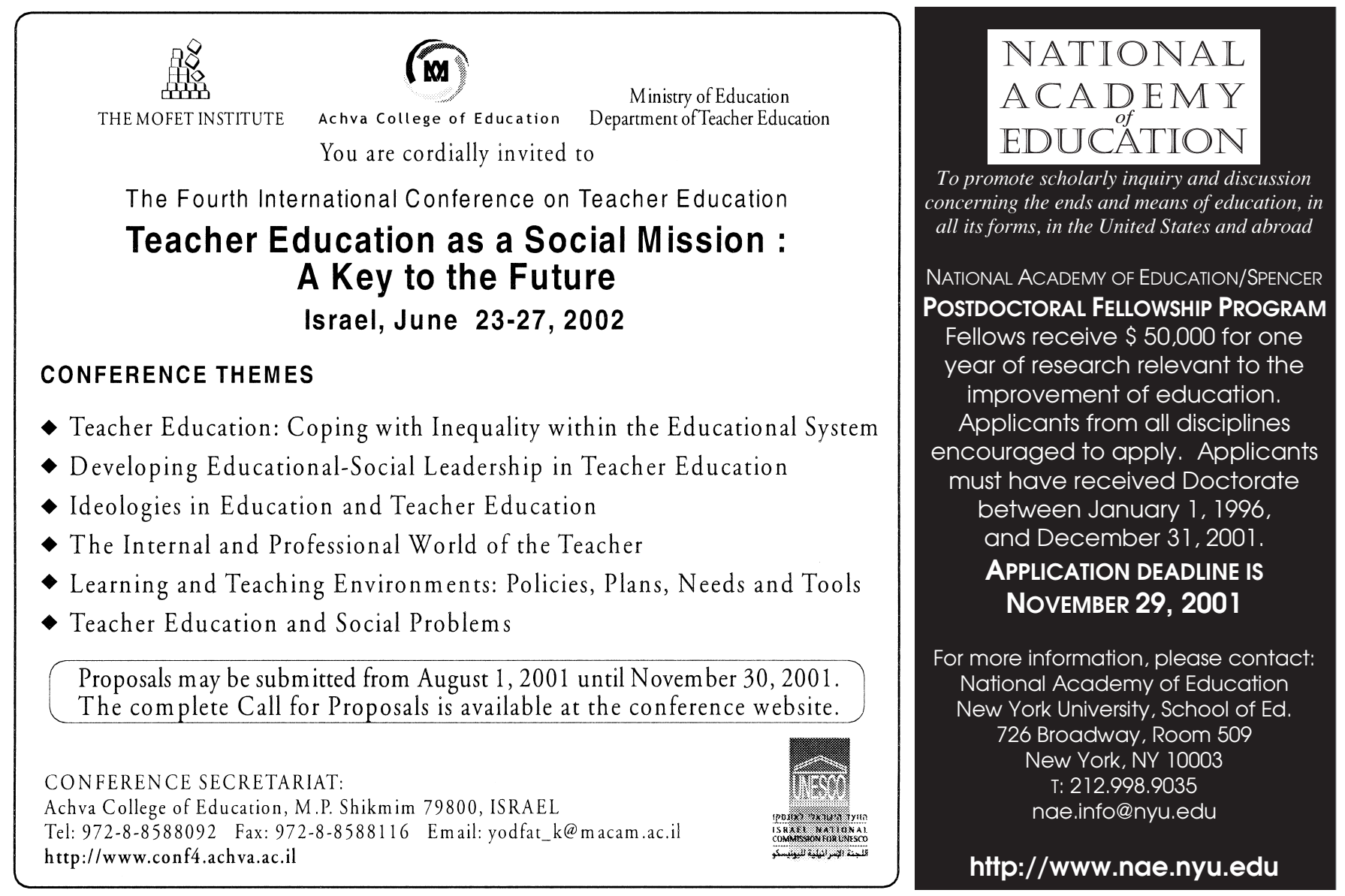

AUGUST/SEPTEMBER 200I 15 


\title{
Educational Researcher, 2000
}

In addition to the reviewers previously acknowledged in the December 2000 issue, interim editors Hilda Borko and Lorrie Shepard would like to thank the following people who reviewed manuscripts in 2000.

\author{
Joseph Becker, University of Illinois at Chicago \\ Mark Berends, RAND \\ David Berliner, Arizona State University \\ Donald Blumenfeld-Jones, Arizona State University \\ Jo Boaler, Stanford University \\ Gary Borich, University of Texas at Austin \\ Ann Brooks, University of Texas at Austin \\ Paul Cobb, Vanderbilt University \\ Donna Deyhle, University of Utah \\ Carol Dwyer, ETS \\ Jacque Eccles, University of Michigan \\ Margaret Eisenhart, University of Colorado at Boulder \\ Edmund Emmer, University of Texas at Austin \\ Susan Empson, University of Texas at Austin \\ Dorothy Espelage, University of Illinois at Urbana-Champaign \\ Colleen Fairbanks, University of Texas at Austin \\ Megan Franke, University of California, Los Angeles \\ Deborah Gallagher, University of Northern Iowa \\ Judith Glazer-Raymo, Long Island University \\ Susan Goldman, Vanderbilt University \\ Patricia Graham, Harvard University \\ Peter Johnston, University of New York at Albany \\ Donna Kirschner, University of Pennsylvania \\ J. Gary Knowles, OISE/University of Toronto \\ Daniel Koretz, RAND \\ Haggai Kupermintz, University of Colorado at Boulder \\ Gerald LeTendre, Pennsylvania State University \\ Allan Luke, University of Queensland, Australia \\ Judit Moschkovich, University of California at Santa Cruz \\ Jim Muchmore, Western Michigan University \\ Norvall Northcutt, University of Texas at Austin \\ Allan Odden, University of Wisconsin at Madison \\ Michael Olivas, University of Houston \\ Arthur Pearl, University of California at Santa Cruz \\ Linda Perkins, City University of New York \\ Paul Pintrich, University of Michigan \\ Stephen Raudenbush, University of Michigan \\ Frank Richardson, University of Texas at Austin \\ Janet Russell, Ohio State University \\ Jo Sanders, Washington Research Institute \\ Jennifer Scott, Longview (TX) ISD \\ Richard Shavelson, Stanford University \\ Bruce Sherin, Northwestern University \\ Keith Stanovich, OISE/University of Toronto \\ Harold Stevenson, University of Michigan \\ Wayne Urban, Georgia State University \\ Howard Wainer, ETS \\ Kathryn Wentzel, University of Maryland at College Park \\ Richard White, Monash University \\ Suzanne Wilson, Michigan State University \\ Kenneth Wolf, University of Colorado at Denver \\ Jo Worthy, University of Texas at Austin \\ Andrea Zetlin, California State University at Los Angeles
}

A special commemorative acknowledgment is also made for the contributions of Richard Jaeger, University of North Carolina at Greensboro. 